\title{
ONLINE KNOWLEDGE SHARING BEHAVIOR THROUGH SOCIAL MEDIA AS A DRIVER FOR ONLINE SHOPPING BEHAVIOR DURING THE COVID-19 PANDEMIC
}

\author{
Yessy Artanti \\ Department of Management, Universitas Negeri Surabaya, Surabaya, Indonesia \\ yessyartanti@unesa.ac.id \\ Widyastuti Widyastuti \\ Department of Management, Universitas Negeri Surabaya, Surabaya, Indonesia \\ widyastuti@unesa.ac.id \\ Monika Tiarawati \\ Department of Management, Universitas Negeri Surabaya, Surabaya, Indonesia \\ monikatiarawat@unesa.ac.id \\ Agus Frianto \\ Department of Management, Universitas Negeri Surabaya, Surabaya, Indonesia \\ agusfrianto@unesa.ac.id
}

\begin{abstract}
Consumer behavior changes are reflected in purchasing decision making. In general, with this pandemic situation, consumers will be motivated to carefully consider each stage of the decision because of the health risks associated with Covid-19 transmission and social distancing rules. This study aims to empirically test the effect of social media marketing and trust on knowledge sharing and online shopping behavior. In this study, the researchers distributed online questionnaires to the respondents and analyzed it using Path analysis tools. The results of this study conclude that social media marketing and trust positively affect information sharing behavior while information sharing behavior also has a significant positive effect on online shopping behavior.
\end{abstract}

Keywords: social media marketing, trust, information sharing behavior, online shopping behavior.

DOI: https://doi.org/10.24818/beman/2021.11.2-02

\section{INTRODUCTION}

The economic impact of the Covid-19 pandemic is so broad and massive that it has completely changed the business's order. This change in business structure adapts to today's consumer behavior. The 


\section{ONLINE KNOWLEDGE SHARING BEHAVIOR THROUGH SOCIAL MEDIA AS A DRIVER FOR ONLINE SHOPPING BEHAVIOR DURING THE COVID-19 PANDEMIC}

purchase decision is one of consumer behavior that determines shopping behavior. Purchase decisions are a consumer response to the influence of the surrounding environment. Meanwhile, shopping behavior leads to online social media in line with the health advisories or protocols during the Covid-19 pandemic. Hence, consumers reduce shopping offline and use more for online shopping. With Covid-19 transmission, consumers are reluctant to visit and get food that consumers prefer to take away or buy it using delivery services. In a study released Wednesday (8/4), Nielsen said that since adopting the stay-at-home appeal to prevent the spread of Covid-19, around $30 \%$ of consumers plan to shop online more frequently. Nielsen's study also said that $80 \%$ of Indonesian consumers access information about Covid-19 through social media, followed by television news $(77 \%)$, and online search engines $(56 \%)$. These three mediums are the source of information most accessed by consumers to find out about the development of Covid-19. As digital technology develops, many companies use social media as a sales promotion tool and disseminating this information is called digital marketing. The means of digital marketing are display marketing, web banner advertising, social media marketing, and email advertising (Pawar, 2014). Social Media Marketing is one of the new and leading marketing efforts that aim to bring consumers as participants rather than observers (Toor et al., 2017). Marketing communications and advertising using social media have undergone a significant transformation over the last decade as new technologies make it more convenient for companies to contact customers (Hongcharu \& Eiamkanchanalai, 2009). Social network marketing is part of Social Media Marketing (Kim \& Ko, 2012). Social networking functions through specific social media sites that allow users to create their profiles, share information, interact and communicate with other users on the same site. (Kaplan \& Haenlein, 2012). The social media that are currently developing are Facebook, Instagram and Twitter. Marketers use Social Media Marketing as a marketing tool because social media is prevalent among individuals. Today's marketing communications present new challenges and opportunities for companies to generate purchases, as people rely more on social media when making purchasing decisions. (Hinz et al., 2011).

In research conducted by (Toor et al., 2017) indicators to measure Social Media Marketing are (1) happy to use social media sites, (2) using social networking sites is fun, (3) the content of social media marketing is impressive, (4) it is easy to send opinions or comments on social networking sites. Meanwhile, (Saher et al., 2016) mentions indicators of Social Media Marketing, namely (1) achieved and (2) learning customer preferences.

The element of trust between people or consumers is also a significant thing to be concerned. Consumers, in the midst of fear and panic caused by the pandemic, are often suspicious of all information or marketing offers made online. Negative emotions are often felt by consumers in the midst of the Covid-19 virus pandemic. The role of social media, elements of trust and sharing of information to encourage safe 
shopping behavior is indispensable in this situation Individuals or consumers trust more information from their group or community and even share information. Sharing information as a member is included in the concept of knowledge sharing behavior. Knowledge sharing behavior can be done when there is interaction and communication between people. Nguyen (2020) revealed that there are three dimensions in online knowledge-sharing behavior which include knowledge donating, knowledge collecting and lurking. Knowledge sharing, especially online knowledge sharing, plays a crucial role in community. Meanwhile, Kim et al. (2020) shows that individuals with higher social skills, closer friendship, and creativity are more likely to encourage knowledge sharing in social networking services (SNS)-based communities. Therefore, this study aims to analyze more deeply how social media marketing, trust, and online knowledge sharing behavior influence online shopping behavior.in pandemic situation.

\section{LITERATURE REVIEW}

\subsection{Social Media Marketing}

The development of social relations through communication in cyberspace is almost identical to the stages of social relations as it should be in the real world. Although there are some differences, the steps in social media are represented by several media systems that replace the role of verbal and nonverbal communication such as text, graphics, images, audio, and video. Nevertheless, there are no direct instructions relating to internet users such as facial expressions, gestures, voice intonation, appearance, or physicality from other users invited to communicate. It is challenging to interpret statements and responses from other users. (Walther, 2006).

The development of social media has an impact on personal and organizational ways of communicating. The advent of Web 2.0 enabled people to build a business and social relationships and share knowledge. Marketing through social media usually important around creating content that grabs attention and encourages readers to share with their social networks. Social media is a platform that is easily accessible to anyone. Even today, someone regardless of the company's role and control can create their content that is interesting and seen by many (Zarrella, 2010). Social media is media designed to facilitate interactive or two-way social interaction. Social media based on internet technology has changed the pattern of disseminating knowledge from one to many audiences (Paramitha, 2011). Social media can take many forms, including internet forums, message boards, weblogs, podcasts, pictures, and videos.

Social media marketing is a form of direct or indirect marketing used to build awareness, recognition, memory, and action for brands, businesses, products, people, or other parties. It is carried out using social Web tools, such as sharing blogging, microblogging, social networking, social bookmarking, and content (Gunelius, 2011). According to Gunelius (2011), the most common goals of social media are (1) 


\section{ONLINE KNOWLEDGE SHARING BEHAVIOR THROUGH SOCIAL MEDIA AS A DRIVER FOR ONLINE SHOPPING BEHAVIOR DURING THE COVID-19 PANDEMIC}

building relationships, (2) building brands, (3) publicity, (4) promotion, and (5) market research. Next, (Gunelius, 2011) also states that there are four pillars of social media marketing: reading, creating, sharing, and discussing.

\subsection{Trust}

Trust is a complex phenomenon, and multiple dimensions of trust operate at various levels of analysis in organizational settings (McAllister, 1995; McKnight et al., 1998; Ring \& van de Ven, 1994; Tsai \& Ghoshal, 1998). However, in its development, trust has been studied in various online contexts. The results show that trust lies in the level of ability, willingness, and integrity of others, which is related to the desire to give and receive information (Ridings et al., 2002) and improved performance in the group (Jarvenpaa et al., 1998). Furthermore, Chiu et al., 2006 and Chow \& Chan, 2008 stated that trust is an individual's belief and expectations that community members can behave consistently by following the norms and principles that apply in the online community.

Social trust is one of the significant determinants of knowledge sharing in online communities (Lin et al., 2009). In an online community, trust between members is seen as a typical attitude towards other online community members. This concept reflects the relationship between members' depth and scope and can cause members to repeatedly visit the same community (Wu et al., 2010). Online communities generally do not have special rules so that it requires all members to behave in general as expected in their social environment (Zhang et al., 2010). Therefore, trust is the most basic subjective alternative to establish a more friendly atmosphere of relationships in online communities.

The trust literature provides sufficient evidence that trusting relationships have led to a greater exchange of knowledge: when trust exists, people are more willing to provide useful knowledge (Levin \& Cross, 2004). According to Mayer et al., 1995, trust means the willingness of a party to be vulnerable to another party's actions. There are three research streams on trust: personality-based trust, institutionalbased trust, and cognition-based trust, which partly explain trust (McKnight et al., 1998). Each stream of research includes several factors: personality-based factors, institution-based factors and cognitionbased factors, which influence trust.

\subsection{Online Knowledge Sharing Behavior}

Online knowledge sharing behavior is unseparated from knowledge sharing activities. The presence of the internet through social media facilitates the speed of activities to share knowledge at any time. Networks and social interactions are increasingly bonded to the sharing of knowledge. There are doubts among researchers about the role of online knowledge sharing behavior through social interactions using social media (Ma \& Chan, 2014). Through their research, Ma \& Chan, 2014 examined the 


\section{ONLINE KNOWLEDGE SHARING BEHAVIOR THROUGH SOCIAL MEDIA AS A DRIVER FOR ONLINE SHOPPING BEHAVIOR DURING THE COVID-19 PANDEMIC}

motivations for online knowledge sharing behavior: perceived online attachment motivation, perceived online relationship commitment, and altruism.

Referring to the four pillars of social media marketing proposed by Gunelius, 2011, sharing online content has two primary forms. First, sharing interesting and useful content found online during reading (first pillar). Using blog posts contains useful tips might help customers. Second, sharing the content created (second pillar). For example, the company was updating presentations through slide shares, videos on YouTube, and Flickr's images. This activity is still included in this activity, namely sharing content to publish online through social media tools, publishing a post on a blog, sharing via Twitter, and communicating through social networks.

Share is an essential measure of viral marketing success, especially on social networking sites and refers to the rate at which users exchange, distribute and receive content (Kietzmann et al., 2011). In the form of social relationships, sharing behavior often involves exchanging content and knowledge between people. In some cases, sharing behavior is often associated with relationships between people (Engeström, 2001). Many terms have the same meaning as the online knowledge sharing behavior. (Atherley, 2011) states that online knowledge sharing behavior is the same as engagement, which means a sharing activity in a group. In social media, engagement activities are shown only through all activities that occur in the online environment. Furthermore, (Siefert et al., 2009) said that engagement is about feelings and emotions. Emotional engagements are positively correlated with the amount of content uploaded, viewed, and comments given.

Several previous studies have examined the factors that influence the sharing viral messages and commercial emails (De Bruyn \& Lilien, 2008; Dobele et al., 2007; Phelps et al., 2004). These studies have identified several essential factors motivating someone to pass several written and commercial viral messages via email, namely, social advantages, self-enrichment, entertainment (amusement), and friends' attachment.

Based on the description, the hypotheses in this study are:

H1: Social media marketing will have a positive effect on online knowledge sharing behavior

H2: Trust will have a positive effect on online knowledge sharing behavior

H3: Online knowledge sharing behavior will have a positive effect on online shopping behavior 


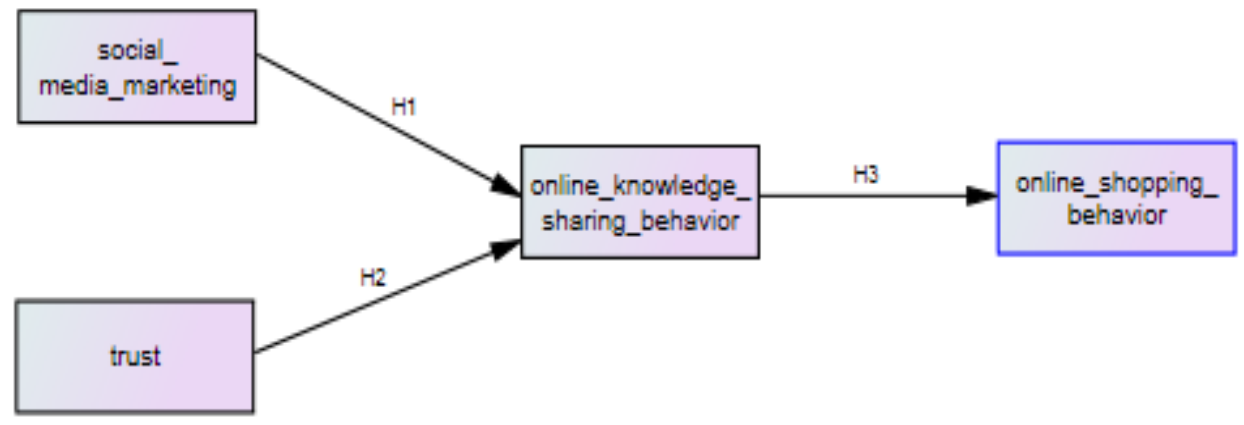

FIGURE 1. RESEARCH MODEL

Source: Authors' research

\section{METHODOLOGY}

This research is a conclusive research that aims to obtain evidence of a causal relationship between marketing through social media and trust in online knowledge sharing behavior and its impact on online shopping behavior. The data collection method is survey method by distributing questionnaires to 200 respondents. Online questionnaires were distributed from May to June 2020. Researchers' efforts to increase the respondent's response (response rates) in this study included not including the identity of the respondent's name. Respondents were asked to respond to statements following their feelings and experiences in carrying out activities related to the research variables. The respondents were unremunerated for their answers. The variables in this study were measured by several statement items using a 5 (five) point Likert scale from 1 (strongly disagree) to 5 (strongly agree). The items of each variable include:

\subsection{Social Media Marketing}

The indicator used to measure social network marketing or social network marketing in this study is to use the hand from Toor et al., 2017 and Kim \& Ko, 2012 which has been adjusted to the research object. Examples of items are "I like to use social networking sites to increase my knowledge of products, services and brands" and "I am satisfied with the social network marketing of a brand that I follow."

\subsection{Trust}

Measurement of trust indicators using items developed by Chiu et al., 2006 consists of 5 items. Examples of items are "Members on my academic social network will not take advantage of others 
despite opportunities" and "Members on my academic social network will always keep the promises they make to each other"

\subsection{Online Knowledge Sharing Behavior}

Measurement of social interaction bond indicators using items developed by (Chiu et al., 2006) consists of 4 items. Examples of items are "the knowledge shared by members of my academic social network is accurate" and "knowledge shared by members of my academic social network is complete."

\subsection{Online Shopping Behavior}

Measuring online shopping behavior using items developed by (Masoud, 2013) which consists of 4 items. Examples of items are "Shopping online is easy to do" and "I shop online to buy products that are not easily available offline."

The following are the statement items in this study.

TABLE 1. MEASUREMENT ITEMS FOR RESEARCH VARIABLES

\begin{tabular}{|c|c|c|}
\hline Variable & Indicator and Statement & References \\
\hline & Increase knowledge & (Toor et al., 2017) \\
\hline \multirow[t]{15}{*}{$\begin{array}{l}\text { Social media } \\
\text { marketing }\end{array}$} & $\begin{array}{l}\text { I feel social media marketing can increase my } \\
\text { knowledge. }\end{array}$ & $\begin{array}{l}\text { and }(\operatorname{Kim} \& \text { Ko, } \\
\text { 2012) }\end{array}$ \\
\hline & $\begin{array}{l}\text { I feel marketing on social media can add to my } \\
\text { knowledge. }\end{array}$ & \\
\hline & Interesting & \\
\hline & I feel social media marketing is interesting & \\
\hline & I feel social media marketing is not boring. & \\
\hline & Interaction & \\
\hline & $\begin{array}{l}\text { I find it is easy to exchange opinions with others on } \\
\text { social media marketing. }\end{array}$ & \\
\hline & $\begin{array}{l}\text { I find it is easy to share information with other users } \\
\text { through marketing on social media. }\end{array}$ & \\
\hline & Entertainment & \\
\hline & $\begin{array}{l}\text { I find it is easy to spend my time visiting marketing } \\
\text { on social media. }\end{array}$ & \\
\hline & $\begin{array}{l}\text { I find it is amusing when I look at marketing on social } \\
\text { media. }\end{array}$ & \\
\hline & I think it is great to visit marketing on social media. & \\
\hline & Trend & \\
\hline & $\begin{array}{l}\text { I think uploads in marketing on social media follow } \\
\text { the current developments. }\end{array}$ & \\
\hline & $\begin{array}{l}\text { I think uploads in marketing on social media follow } \\
\text { the tastes of social media followers. }\end{array}$ & \\
\hline Trust & $\begin{array}{l}\text { I believe the members of my community will always } \\
\text { try to help if I face difficulties. }\end{array}$ & (Chiu et al., 2006) \\
\hline
\end{tabular}


Artanti, Y., Widyastuti, W., Tiarawati, M. \& Frianto, A.

Online

knowledge

sharing

behavior

Online shopping behavior
I believe members of my community will always stretch out a hand if I need it.

I believe my community members behave consistently in the community.

I believe my community members can keep their promises as conveyed in the community.

I trust the members of my community always to be honest with each other.

The knowledge shared by my social network (Chiu et al., 2006) members is accurate.

The knowledge shared by members of my social network is complete.

The knowledge shared by members of my social network is reliable.

Knowledge shared by members of my social networks on time

I buy products through online sites/media according (Masoud, 2013) to my needs.

Before I shop through online sites/media, I look for information about online sites/media.

Shopping online is an alternative option to meet my needs.

I believe buying through online sites/media is the right decision.

Source: author

\section{RESULTS}

\subsection{Respondent Characteristics}

The online questionnaires were distributed to 200 respondents with an age range of 20 - 60 years.

Table 2 presents the descriptions of the respondent characteristics in this study.

TABLE 2. RESPONDENT CHARACTERISTICS

\begin{tabular}{lccc}
\hline Characteristic & Category & Amount & Percentage (\%) \\
\hline Age & $20-30$ years-old & 49 & $24.5 \%$ \\
& $31-40$ years-old & 83 & $41.5 \%$ \\
& $41-50$ years-old & 56 & $28 \%$ \\
& $51-60$ years-old & 12 & $6 \%$ \\
Occupation & Housewife & 50 & $25 \%$ \\
& Private sector-worker & 89 & $44.5 \%$ \\
& Civil servant & 26 & $13 \%$ \\
& Entrepreneur & 35 & $17.5 \%$ \\
\hline Total & & $\mathbf{2 0 0}$ & $\mathbf{1 0 0} \%$ \\
\hline
\end{tabular}

Source: author 
Artanti, Y., Widyastuti, W., Tiarawati, M. \& Frianto, A.

ONLINE KNOWLEDGE SHARING BEHAVIOR THROUGH SOCIAL MEDIA AS A DRIVER FOR ONLINE SHOPPING BEHAVIOR DURING THE COVID-19 PANDEMIC

Table 2 reveals that most of the respondents are aged 31 - 40 years, and the majority work as private employees. As for the social media or marketplaces that they often visit for various purposes, they are as follows at Table 3. Table 3 shows that the most frequently used or visited social media or marketplaces consecutively are: Shopee, WhatsApp, Instagram, Tokopedia, Facebook, Lazada, and Bukalapak. In filling out the questionnaire for this item, respondents can answer more than 1 (one) social media or marketplace used.

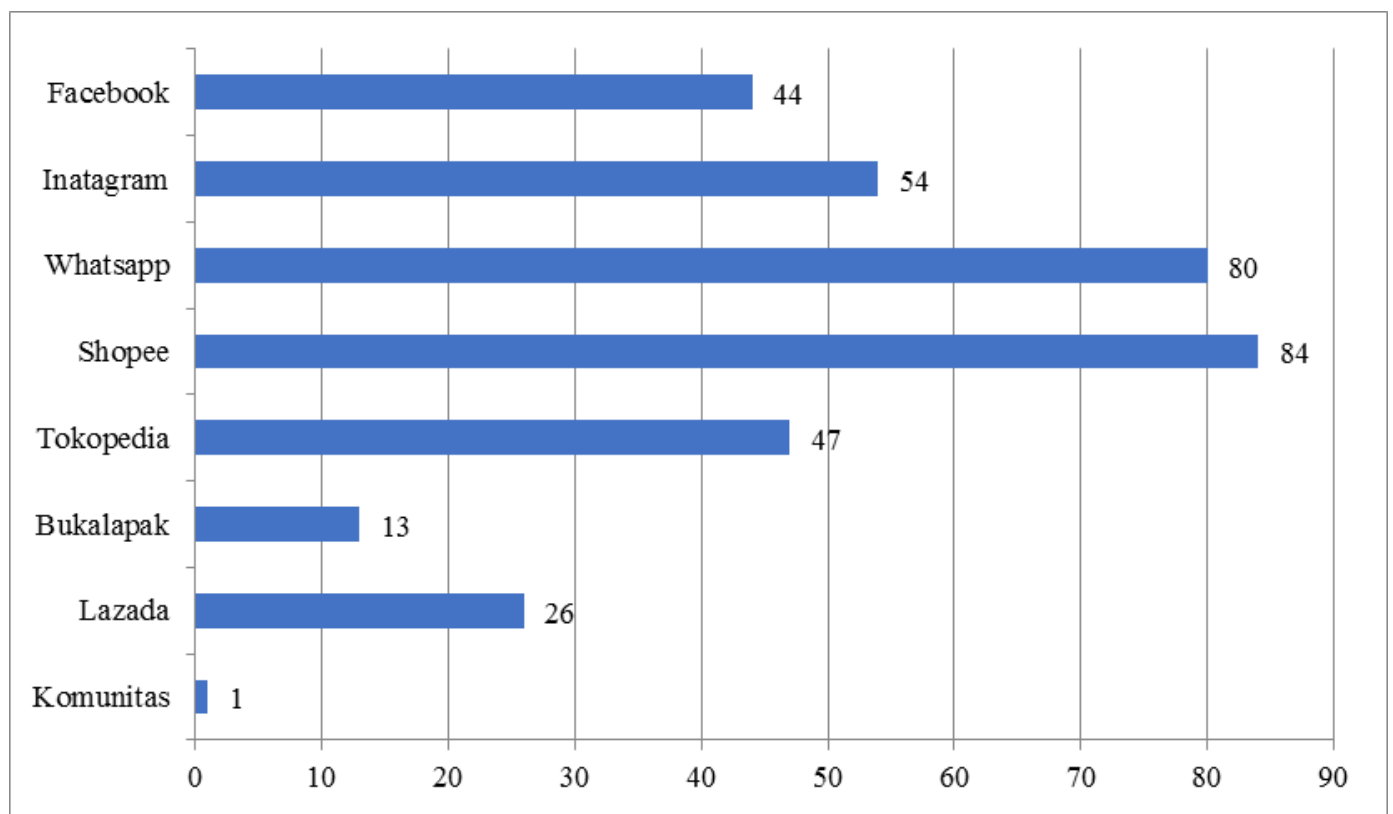

TABLE 3. MOST USED / VISITED SOCIAL MEDIA AND MARKETPLACES FOR SHOPPING

Source: author

\subsection{Validity and Reliability Test}

This study's validity test was carried out by looking at the correlation value between items and the total value. If $r$ count $>r$ table is positive, then the item or statement or indicator can be declared valid (Sekaran \& Bougie, 2010). In this study, the $r$ table used was 0.3610 . If $r$ count> 0.3610 the statement item can be said to be valid and can be continued to the next stage. Meanwhile, reliability testing in this study was carried out by looking at the Cronbach's Alpha value, where the value must be greater than 0.70 (Sekaran \& Bougie, 2010).

TABLE 4. VALIDITY AND RELIABILITY TEST RESULT

\begin{tabular}{ccc}
\hline Variable & \multicolumn{1}{c}{ Indicator and Statements } & Coefficient Correlation \\
\hline Social Media Marketing (Cronbach Alpha = 0.932 ) & \\
& I feel marketing on social media can increase my knowledge & 0,837 \\
I feel marketing on social media can add to my knowledge & 0,808 \\
I find marketing on social media interesting & 0,794 \\
\hline
\end{tabular}


Artanti, Y., Widyastuti, W., Tiarawati, M. \& Frianto, A.

ONLINE KNOWLEDGE SHARING BEHAVIOR THROUGH SOCIAL MEDIA AS A DRIVER FOR ONLINE SHOPPING BEHAVIOR DURING THE COVID-19 PANDEMIC

Trust (Cronbach Alpha $\mathbf{0} \mathbf{0 . 8 6 9})$

I feel that marketing on social media is not boring

0,837

I find it is easy to exchange opinions with others on social

0,592

media marketing

I find it is easy to share information with other users through

0,794

marketing on social media

I find it is easy to spend my time visiting marketing on social

0,767

media

I find it is amusing when I look at marketing on social media $\quad 0,767$

I think it is great to visit marketing on social media $\quad 0,797$

I think social media marketing contents follow the current $\quad 0,797$

developments

I think social media marketing contents follow the tastes of $\quad 0,808$

its followers

I believe members of my community will always try to help if

I face difficulties

I believe members of my community will always stretch out a

hand if I need it

I believe my community members behave consistently in the

0,935

community

I believe my community members can keep their promises

0,905

as conveyed in the community

I trust members of my community always to be honest with

0,819

each other

Online knowledge sharing behavior (Cronbach Alpha $=0.853$ )

The knowledge shared by my social network members is

accurate

The knowledge shared by members of my social network is

complete

The knowledge shared by members of my social network is

reliable

Knowledge shared by members of my social networks on

time

Online shopping behavior (Cronbach Alpha $=0.725$ )

I buy products through online sites/media according to my

needs

Before I shop through online sites/media, I look for

information about online sites/media

Shopping online is an alternative option to meet my needs

0,808

I believe buying through online sites/media is the right

0,612 decision

Source: Data processed by authors

Based on table 4, it can be seen that all statement items are valid because $r$ count> $r$ table $(0.3610)$. Likewise, the reliability test, all items have a value> 0.70 (Sekaran \& Bougie, 2010) so that the statement items can be said to be reliable. Thus, all statement items can be used as benchmarks for 
social media marketing and trust in online shopping behavior with online knowledge sharing behavior as a mediating variable.

\subsection{Model Feasibility Test}

A model feasibility test is used to evaluate the model's suitability through various criteria of goodness of fit multiple correlations (R2). The coefficient of determination (R2) is one of the references in testing a model's feasibility or accuracy. The coefficient of determination is defined as how strong the independent variable's ability to explain the dependent variable.

\section{TABLE 5. MODEL FEASIBILITY TEST}

\begin{tabular}{ll}
\hline & Estimate \\
\hline Online knowledge sharing behavior & 0,149 \\
\hline Online shopping behavior & 0,089 \\
\hline \multicolumn{2}{c}{ Source: Data processed by authors }
\end{tabular}

Table 5 shows that the coefficient of determination $\left(R^{2}\right)$ of social media marketing and trust $\left(R^{2}\right)$ is 0.149 , meaning that the influence of the variable online knowledge sharing behavior due to social media marketing variables and trust is $14.9 \%$. While the coefficient of determination $\left(R^{2}\right)$ of social media marketing and trust on online shopping behavior $\left(R^{2}\right)$ is 0.089 , the influence of social media marketing variables and trust and online knowledge sharing behavior on online shopping behavior is $8.9 \%$.

\subsection{Hypothesis Testing Result}

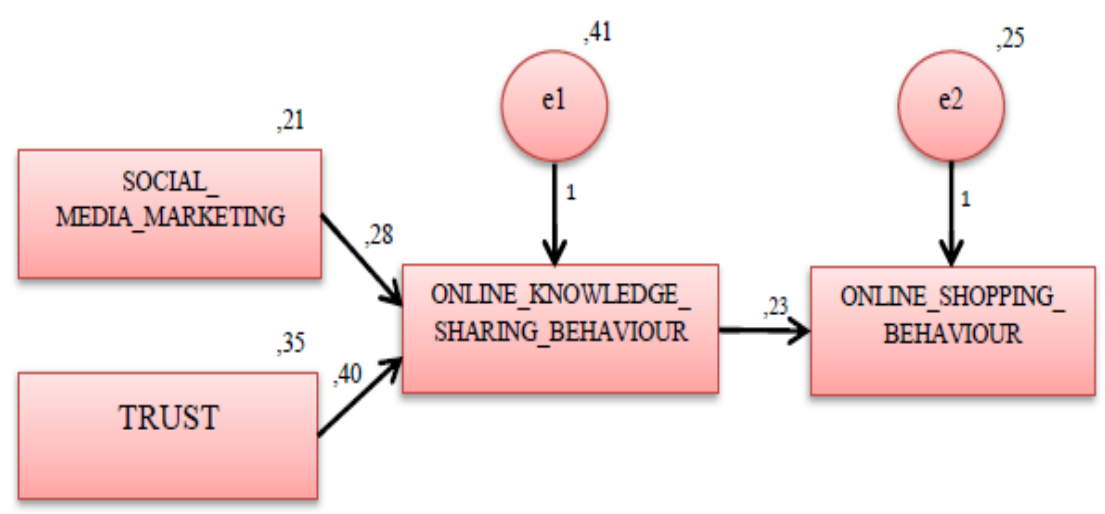

FIGURE 2. PATH ANALYSIS RESULT

Source: Data processed by authors 
Artanti, Y., Widyastuti, W., Tiarawati, M. \& Frianto, A.

ONLINE KNOWLEDGE SHARING BEHAVIOR THROUGH SOCIAL MEDIA AS A DRIVER FOR ONLINE SHOPPING BEHAVIOR DURING THE COVID-19 PANDEMIC

TABLE 6. STANDARDIZED REGRESSION WEIGHTS

\begin{tabular}{lccc}
\hline & Estimate & CR & P \\
\hline $\begin{array}{l}\text { Social media marketing } \rightarrow \text { Online } \\
\text { knowledge sharing behavior }\end{array}$ & 0,281 & 2,34 & 0,019 \\
\hline $\begin{array}{l}\text { Trust } \rightarrow \text { Online knowledge sharing } \\
\text { behavior }\end{array}$ & 0,397 & 4,308 & 0,000 \\
\hline $\begin{array}{l}\text { Online knowledge sharing behavior } \\
\rightarrow \text { Online shopping behavior }\end{array}$ & 0,225 & 3,872 & 0,000 \\
\hline
\end{tabular}

Source: Data processed by authors

Based on Figure 1 and Table 6, hypothesis testing explained by the following description:

a. Hypothesis 1

In the relationship between social media marketing and online knowledge sharing behavior, the $C R$ value is $2.34>2.00$, and the significance value is $0.019<0.05$, so hypothesis 1 is accepted. It means that social media marketing has a significant effect on online knowledge sharing behavior.

b. Hypothesis 2

In the relationship between trust and online knowledge sharing behavior, the CR value is $4.308>2.00$, and the significance value is $0.000<0.05$, then hypothesis 2 is accepted. It means that trust has a positive effect on online knowledge sharing behavior.

c. Hypothesis 3

In the relationship between online knowledge sharing behavior and online shopping behavior, the $C R$ value is $3,872>2.00$, and the significance value is $0,000<0.05$, then hypothesis 3 is accepted. It means that there is a positive influence on online knowledge sharing behavior on online shopping behavior.

\section{DISCUSSION}

Based on the data analysis that has been done, it shows that social media marketing has a positive effect on online knowledge sharing behavior. It means that when social media marketing increases, online knowledge sharing behavior increases as well. Many marketers use sharing behavior such as sharing content, blogs, vlogs, and various posts on social media to market their business. Some customers may prefer marketing by online knowledge sharing behavior because it looks more real, natural and without exaggeration. Even some of us believe word of mouth more than advertisements. When a consumer is exposed to or sees various information on social media, the consumer who is a group member or group will immediately share information with other members. This often occurs in a group or group whose members consist of housewives. Especially in the current pandemic season, all 


\section{ONLINE KNOWLEDGE SHARING BEHAVIOR THROUGH SOCIAL MEDIA AS A DRIVER FOR ONLINE SHOPPING BEHAVIOR DURING THE COVID-19 PANDEMIC}

information on social media, especially those related to health products for individuals or families, will spread quickly among a group or group members.

According to Gunelius, 2011, online content sharing can be done in two ways. The first thing customers find while reading is a few helpful tips. Usually, it can be found on blogs, Facebook, Twitter and other social networking tools with basic writing. Marketer also could use visual content such as presentations on share slides, videos on YouTube, and images on Flickr. According to Ghahtarani et al., 2020, his research results show that the social media dimension impacts knowledge sharing behavior. Besides, the study results indicate that interactions through social media and perceived benefits affect knowledge sharing behavior. Sophisticated social media has offered unique features by introducing new platforms where hundreds or even thousands of people worldwide can interact with each other and produce information or content online (Kwahk \& Park, 2016).

The influencer boom nowadays has a significant impact on marketing. Social media is used significantly in people's social activities. It has drastically changed users to contribute to public knowledge, share information and their experiences with friends, family and markets (Chang \& Chuang, 2011). It is starting from an honest review of a product that gets a positive response from viewers. They believe that reviews could be more than advertisements that make marketers take advantage. Therefore, what initially obtained from one audience to many audiences can now be patterned (Paramitha, 2011). This is because the free interaction on social media makes the distribution of information very fast. Furthermore, marketers are more likely to use influencers to persuade their audience, considering that they trust influencers more than advertisements.

Trust is an essential element for maintaining exchange relations between members in a group. Members are more willing to interact and share or exchange knowledge if there is trust among themselves. In this case, trust is considered a belief in reliability and integrity among group members. Based on the results of data analysis, it can be concluded that trust has a positive effect on online knowledge sharing behavior. It means that every trust has increased, the online knowledge sharing behavior will also increase. Social trust is one of the significant determinants of knowledge sharing in online communities (Lin et al., 2009). In the online knowledge sharing behavior, it is obligatory to have trust between them. According to (Levin \& Cross, 2004), people are more willing to provide useful knowledge when there is belief. In the sharing information behavior, someone will receive information from those who are trusted and vice versa. Someone who is trusted in providing information will provide information that is useful for the audience's needs, from the trust that the audience places on influencers to make marketers see this as a marketing opportunity. The existence of trust makes the information provided by influencers readily accepted by the audience. For this reason, marketers use 


\section{ONLINE KNOWLEDGE SHARING BEHAVIOR THROUGH SOCIAL MEDIA AS A DRIVER FOR ONLINE SHOPPING BEHAVIOR DURING THE COVID-19 PANDEMIC}

influencers to convey information about products to make it easier for the audience to arrive and understand.

Several previous studies have had mixed results on this research relationship. (Bakker et al., 2006) found a negative influence between trust and knowledge sharing in a group. Then, Swift \& Hwang, 2013 found positive but insignificant results in the impact of trust and knowledge sharing. (Ko, 2010) also found no positive influence between trust and knowledge sharing. Meanwhile, according to (Levin \& Cross, 2004), the results of a positive impact between trust and knowledge sharing. Rutten et al., 2016 also state that there is a positive relationship between trust and knowledge sharing. However, Ghahtarani et al. (2020) clearly states that the relationship between trust and sharing behavior is rejected.

From the research results, it can be seen that online knowledge sharing behavior has a positive effect on online shopping behavior. It means that if online knowledge sharing behavior increases, it will encourage an increase in online shopping behavior (Ghahtarani et al., 2020) knowledge sharing behavior has an impact on consumer shopping behavior. It is because sharing knowledge/information affects consumers' thinking, feelings and needs. Through social media platforms, users share their ideas and thoughts. Purchase intention or shopping behavior is a personal one that can be influenced through information and emotional processes. Sharing knowledge can impact purchase intentions because people can make wise decisions in making purchases with knowledge about products and services.

\section{CONCLUSION AND IMPLICATION}

In this study, the researcher proposes a research model integrating social media marketing, trust, information sharing and shopping behavior. Through empirical research, this study examines the effect of social media marketing and trust on information-sharing behavior and its impact on shopping behavior among, housewives who are members of an online group or group. Hypothesis testing results show that: Hypothesis 1, which tests the effect of social media marketing on online knowledge sharing behavior, is fully supported. Hypothesis 2, which examines the impact of trust on online knowledge sharing behavior, is also fully supported. Hypothesis 3 , which states that online knowledge sharing behavior affects online shopping behavior, is proven to be accepted.

The implications of this study are inseparable from several limitations or obstacles. First, the respondents of this study were limited to housewives and this occurred during the Covid-19 pandemic, so it cannot be generalized if this research is applied to normal conditions. Second, this study limits the use of specific measurement scales. Many different measurement scales have been developed to 
measure the same construct. This results in the results of research where using different scales is not impossible to give better results. Hence, uniformity of scale on several other constructs will disturb respondents' attitudes and perceptions. It is recommended for future research to use different measurement scales even for the same construct.

\section{REFERENCES}

Atherley, R. (2011). What Does Engagement Mean to Your Stakeholders? /ahacreative.com/what-doesengagement-mean-to-your-stakeholders/

Bakker, M., Leenders, R. T. A. J., Gabbay, S. M., Kratzer, J., \& Van Engelen, J. M. L. (2006). Is trust really social capital? Knowledge sharing in product development projects. Learning Organization, 13(6), 594-605. https://doi.org/10.1108/09696470610705479

Chang, H. H., \& Chuang, S.-S. (2011). Social capital and individual motivations on knowledge sharing: Participant involvement as a moderator. Information \& Management, 48(1), 9-18. https://doi.org/https://doi.org/10.1016/j.im.2010.11.001

Chiu, C.-M., Hsu, M.-H., \& Wang, E. T. G. (2006). Understanding knowledge sharing in virtual communities: An integration of social capital and social cognitive theories. Decision Support Systems, 42(3), 1872-1888. https://doi.org/10.1016/i.dss.2006.04.001

Chow, W. S., \& Chan, L. S. (2008). Social network, social trust and shared goals in organizational knowledge sharing. Information and Management, 45(7), 458-465. https://doi.org/10.1016/j.im.2008.06.007

De Bruyn, A., \& Lilien, G. L. (2008). A multi-stage model of word-of-mouth influence through viral marketing. International Journal of Research in Marketing, 25(3), 151-163. https://doi.org/10.1016/i.jiresmar.2008.03.004

Dobele, A., Lindgreen, A., Beverland, M., Vanhamme, J., \& van Wijk, R. (2007). Why pass on viral messages? Because they connect emotionally. Business Horizons, 50(4), 291-304. https://doi.org/10.1016/j.bushor.2007.01.004

Engeström, Y. (2001). Expansive Learning at Work: Toward an activity theoretical reconceptualization. Journal of Education and Work, 14(1), 133-156. https://doi.org/10.1080/13639080020028747

Ghahtarani, A., Sheikhmohammady, M., \& Rostami, M. (2020). The impact of social capital and social interaction on customers' purchase intention, considering knowledge sharing in social commerce context. Journal of Innovation and Knowledge, 5(3), 191-199. https://doi.org/10.1016/j.jik.2019.08.004

Gunelius, S. (2011). 30-Minutes SOCIAL MEDIA Marketing.

Hinz, O., Skiera, B., Barrot, C., \& Becker, J. U. (2011). Seeding strategies for viral marketing: An empirical comparison. Journal of Marketing, 75(6), 55-71. https://doi.org/10.1509/jm.10.0088

Hongcharu, B., \& Eiamkanchanalai, S. (2009). A Comparative Study Of Traditional Mass Media, The Internet And Mobile Phones For Integrated Marketing Communications. Journal of Business \& Economics Research, 7(12), 31-40. http://ezproxy.unal.edu.co/docview/194884689?accountid $=137090$ 
Jarvenpaa, S. L., Knoll, K., \& Leidner, D. E. (1998). Is Anybody out There? Antecedents of Trust in Global Virtual Teams. Journal of Management Information Systems, 14(4), 29-64. http://www.jstor.org/stable/40398291

Kaplan, A. M., \& Haenlein, M. (2012). Social media : back to the roots and back to the future. 14(2), 101-104. https://doi.org/10.1108/13287261211232126

Kietzmann, J. H., Hermkens, K., McCarthy, I. P., \& Silvestre, B. S. (2011). Social media? Get serious! Understanding the functional building blocks of social media. Business Horizons, 54(3), 241-251. https://doi.org/10.1016/i.bushor.2011.01.005

Kim, A. J., \& Ko, E. (2012). Do social media marketing activities enhance customer equity? An empirical study of luxury fashion brand. Journal of Business Research, 65(10), 1480-1486. https://doi.org/https://doi.org/10.1016/j.jbusres.2011.10.014

Kim, Hannah \& Lee, Jeongmin \& Oh, Sung. (2019). Individual characteristics influencing the sharing of knowledge on social networking services: online identity, self-efficacy, and knowledge sharing $\begin{array}{lllll}\text { intentions. Behaviour \& Information } \quad \text { Technology. } & 39 . & 1-12 .\end{array}$ https://doi.org/10.1080/0144929X.2019.1598494

Ko, D. G. (2010). Consultant competence trust doesn't pay off, but benevolent trust does! Managing knowledge with care. Journal of Knowledge Management, 14(2), 202-213. https://doi.org/10.1108/13673271011032355

Kwahk, K. Y., \& Park, D. H. (2016). The effects of network sharing on knowledge-sharing activities and job performance in enterprise social media environments. Computers in Human Behavior, 55, 826839. https://doi.org/10.1016/j.chb.2015.09.044

Levin, D. Z., \& Cross, R. (2004). The Strength of Weak Ties You Can Trust: The Mediating Role of Trust in Effective Knowledge Transfer. Management Science, 50(11), 1477-1490. https://doi.org/10.1287/mnsc.1030.0136

Lin, M. J. J., Hung, S. W., \& Chen, C. J. (2009). Fostering the determinants of knowledge sharing in professional virtual communities. Computers in Human Behavior, 25(4), 929-939. https://doi.org/10.1016/i.chb.2009.03.008

Ma, W. W. K., \& Chan, A. (2014). Knowledge sharing and social media: Altruism, perceived online attachment motivation, and perceived online relationship commitment. Computers in Human Behavior, 39(April), 51-58. https://doi.org/10.1016/j.chb.2014.06.015

Masoud, E. Y. (2013). The Effect of Perceived Risk on Online Shopping in Jordan. European Journal of Business and Management, 5(6), 76-88.

Mayer, R. C. ., Davis, J. H. ., \& Schoorman, F. . D. (1995). An Integrative Model of Organizational Trust. Academy of Management Review, 20(3), 709-734.

McAllister, D. J. (1995). Affect- and cognition-based trust as foundations for interpersonal cooperation in organizations. In Academy of Management Journal (Vol. 38, Issue 1, pp. 24-59). Academy of Management. https://doi.org/10.2307/256727

McKnight, D. H., Cummings, L. L., \& Chervany, N. L. (1998). Initial Trust Formation in New Organizational Relationships. The Academy of Management Review, 23(3), 473-490. https://doi.org/10.2307/259290

Nguyen, T.-M. (2021), "Four-dimensional model: a literature review in online organisational knowledge sharing", VINE Journal of Information and Knowledge Management Systems, Vol. 51 No. 1, pp. 109138. https://doi.org/10.1108/VJIKMS-05-2019-0077 


\section{ONLINE KNOWLEDGE SHARING BEHAVIOR THROUGH SOCIAL MEDIA AS A DRIVER FOR ONLINE SHOPPING BEHAVIOR DURING THE COVID-19 PANDEMIC}

Paramitha, C. R. P. (2011). Analisis Faktor Pengaruh Promosi Berbasis Sosial Media Terhadap Keputusan Pembelian Pelanggan dalam Bidang Kuliner. Bina Nusantara.

Pawar, M. (2014). Social work practice with local communities in developing countries: Imperatives for political engagement. SAGE Open, 4(2). https://doi.org/10.1177/2158244014538640

Phelps, J. E., Lewis, R., Mobilio, L., Perry, D., \& Raman, N. (2004). Viral marketing or electronic wordof-mouth advertising: Examining consumer responses and motivations to pass along email. Journal of Advertising Research, 44(4), 333-348. https://doi.org/10.1017/S0021849904040371

Ridings, C. M., Gefen, D., \& Arinze, B. (2002). Some antecedents and effects of trust in virtual communities. Journal of Strategic Information Systems, 11(3-4), 271-295. https://doi.org/10.1016/S0963-8687(02)00021-5

Ring, P. S., \& van de Ven, A. H. (1994). Developmental Processes of Cooperative Interorganizational Relationships. The Academy of Management Review, 19(1), 90-118. https://doi.org/10.2307/258836

Rutten, W., Blaas - Franken, J., \& Martin, H. (2016). The impact of (low) trust on knowledge sharing. Journal of Knowledge Management, 20(2), 199-214. https://doi.org/10.1108/JKM-10-2015-0391

Saher, S., Ramzan, N., Faheem, M., \& Rafique, A. (2016). Influence Of Credible Social Media Marketing On Purchase Intentions Of Females Of Pakistan For Clothing Brand . 28(4), 35-38.

Sekaran, U., \& Bougie, R. (2010). Research Methods for Business (5th ed.). John Wiley \& Sons Ltd.

Siefert, C. J., Kothuri, R., Jacobs, D. B., Levine, B., Marci, C. D., \& Plummer, J. (2009). Winning the super "buzz" bowl: How biometrically-based emotional engagement correlates with online views and comments for super bowl advertisements. Journal of Advertising Research, 49(3), 293-303. https://doi.org/10.2501/S0021849909090424

Swift, P. E., \& Hwang, A. (2013). The impact of affective and cognitive trust on knowledge sharing and organizational learning. Learning Organization, 20(1), 20-37. https://doi.org/10.1108/09696471311288500

Toor, A., Husnain, M., \& Hussain, T. (2017). The impact of social network marketing on consumer purchase intention in Pakistan: Consumer engagement as a mediator. Asian Journal of Business and Accounting, 10(1), 167-199.

Tsai, W., \& Ghoshal, S. (1998). Social Capital and Value Creation: The Role of Intrafirm Networks. The Academy of Management Journal, 41(4), 464-476. https://doi.org/10.2307/257085

Walther, A. (2006). Regimes of youth transitions: Choice, flexibility and security in young people's experiences across different European contexts. YOUNG, 14(2), 119-139. https://doi.org/10.1177/1103308806062737

Wu, J. J., Chen, Y. H., \& Chung, Y. S. (2010). Trust factors influencing virtual community members: A study of transaction communities. Journal of Business Research, 63(9-10), 1025-1032. https://doi.org/10.1016/j.jbusres.2009.03.022

Zarrella, D. (2010). the Social Media Marketing Book (1st ed.). O'Reilly Media, Inc.

Zhang, W., Johnson, T. J., Seltzer, T., \& Bichard, S. L. (2010). The Revolution Will Be Networked. Soc. Sci. Comput. Rev., 28(1), 75-92. https://doi.org/10.1177/0894439309335162 